\title{
KEIGO DAN MUDHA KRAMA : RAGAM HORMAT PADA MASYARAKAT JEPANG DAN JAWA
}

\author{
Devita Widyaningtyas Yogyanti ${ }^{1}$, Mery Kharismawati ${ }^{2}$ \\ ${ }^{1}$ Universitas Bina Sarana Informatika, devita.ded@bsi@ac.id \\ ${ }^{2}$ Universitas Gadjah Mada, mery.kharismawati@ugm.ac.id
}

\begin{abstract}
ABSTRAK
Penelitian ini adalah penelitian kualitiatif mengenai perbandingan budaya. Dalam hal ini, bentuk budaya yang dibandingkan adalah ragam bahasa hormat dalam Bahasa Jawa dan Jepang. Penelitian bertujuan untuk membandingkan dan mengetahui peranan ragam hormat dalam generasi muda di Jawa dan Jepang. Dari hasil penelitian diketahui bahwa ragam hormat dalam bahasa Jawa dan Jepang terdiri dari beberapa tingkatan bahasa. Tingkatan ragam hormat dalam bahasa Jepang adalah Sonkeigo, Kenjoogo dan Teineigo sedangkan dalam tingkatan ragam hormat dalam bahasa Jawa adalah Mudha Krama yang terbentuk dari Krama Inggil, Krama Andhap dan Krama. Dalam bahasa Jepang ragam hormat direalisasikan menggunakan leksem serta bentuk sintaktis, sedangkan dalam bahasa Jawa direalisasikan dengan leksem dan afiks. Pada perkembangannya bahasa Jawa semakin jarang digunakan di masyarakat Jawa karena fungsi basa krama telah digantikan oleh bahasa nasional, yaitu bahasa Indonesia, sehingga tidak ada kepentingan bagi generasi muda untuk menguasainya. Hal ini berbeda dengan keigo, yang hingga saat ini masih aktif digunakan dan dipelajari generasi muda Jepang yang ingin sukses dalam berkarir dan berkehidupan sosial.
\end{abstract}

Kata kunci : keigo, mudha krama, ragam hormat, perbandingan

\section{ABSTRACT}

This research is qualitative research about cultural comparison. The cultures being compared are Javanese and Japanese language honorific forms. The aims of this research are to compare and examine the roles of honorific form in the Javanese and Japanese young generations. The result shows that honorific forms in Javanese and Japanese consist of language levels. Sonkeigo, Kenjoogo, Teineigo are the variety of honorific forms (Keigo) in Japanese, while in Javanese the variety of honorific forms is indicated by Mudha Krama which has 3 variants, Krama Inggil, krama Andhap, and krama. In Japanese, the honorific style is realized using lexemes and syntactic forms, while in Javanese it is defined by lexemes and affixes. In its development, the Javanese language is become rarely used in Javanese society because the basic manner function has been replaced by the national language (Bahasa Indonesia. So there is no urgency for the young generation to master it. This is different from Keigo, which is actively used and studied by the recent Japanese generation who want to be successful in their careers and social life.

Keywords: keigo, mudha krama, honorific form, comparation

ISSN: 2355-6587, e-ISSN: 2528-2220

http://ejournal.bsi.ac.id/ejurnal/index.php/jp 


\section{PENDAHULUAN}

Dalam masyarakat Jawa maupun Jepang, tingkat tutur menunjukkan dua hal yaitu tingkat formalitas dan tingkat respek yang dirasakan seseorang terhadap lawan bicara (Poedjosoedarmo, 1968: 56, Imtihani, 2000: 6). Dalam bahasa Jawa, ragam hormat disebut sebagai Basa Krama, sedangkan dalam bahasa Jepang disebut sebagai Keigo. Sama seperti Basa Krama, Keigo (baik kosa kata maupun pembentukan ragam hormat yang bersifat sintaktis) juga berfungsi untuk menunjukkan formalitas dan respek kepada lawan bicara (Imtihani, 2000: 6)

Baik basa Krama dan Keigo dibagi lagi ke dalam beberapa jenis ragam lagi. Dalam bahasa Jawa, basa krama dibagi menjadi tiga berdasarkan siapa peserta yang terlibat dalam pembicaraan. Jenis pertama adalah Mudha Krama. Mudha Krama adalah bentuk yang paling sopan dan paling formal. Jenis ini digunakan oleh pembicara yang statusnya lebih inferior kepada lawan tutur yang lebih superior, yang muda kepada yang lebih tua. Krama jenis ini mengandung imbuhanimbuhan yang memperhalus tuturan, dan kata-kata basa Krama, Krama Inggil serta Krama Andhap. Jenis ini juga dapat digunakan untuk mengacu pada orang ketiga.

Jenis kedua adalah Kramantara. Jenis ini digunakan oleh orang dengan kedudukan yang setara. Jenis ini mengandung imbuhan-imbuhan yang memperhalus tuturan dan kata-kata Basa Krama. Namun jenis ini tidak digunakan untuk berbicara kepada orang kedua melainkan kepada orang ketiga (orang asing yang tidak begitu dikenal).

Jenis ketiga adalah Wredhakrama. Jenis ini digunakan oleh orang tua kepada yang lebih muda yang mempunyai posisi atau status yang lebih tinggi darinya. Jenis ini mengandung kata-kata Basa Krama namun imbuhanimbuhan yang memperhalus tuturan tidak digunakan.

Sedangkan dalam Bahasa Jepang, bahasa sopan dibagi menjadi tiga jenis.
Jenis pertama adalah Sonkeigo. Jenis ini adalah bahasa sopan yang dilakukan dengan menggunakan diksi dan tata bahasa untuk meninggikan derajat lawan bicara ataupun orang ketiga. Hal yang ditinggikan bisa berupa benda-benda, keadaan, aktivitas maupun hal-hal lain yang berhubungan dengan lawan bicara atau orang ketiga. Jenis ini digunakan oleh orang yang berkedudukan rendah kepada orang yang berkedudukan lebih tinggi (Shotaro dalam Sudjianto-Dahidi, 2004:190)

Jenis kedua adalah Kenjoogo. Jenis ini dilakukan dengan merendahkan diri sendiri dengan tujuan menghormati orang lain. Yang ditinggikan bisa berupa benda-benda, keadaan, aktifitas maupun hal-hal lain yang berhubungan dengan lawan bicara atau orang ketiga. Digunakan oleh orang yang berkedudukan rendah kepada orang yang berkedudukan lebih tinggi (Hirai dalam Sudjianto-Dahidi, 2004:192).

Jenis ketiga adalah Teineigo. Jenis ini bersifat netral namun tetap berfungsi sebagai bentuk saling menghormati dan menghargai perasaan masing-masing. Bisa dikatakan jenis ini menunjukkan kesetaraan antara penutur (Bunkachoo dalam Sudjianto-Dahidi, 2004: 194).

Sistem ragam hormat dalam bahasa Jepang sama seperti sistem Mudha Krama dalam bahasa Jawa yang di dalamnya terdapat unsur-unsur yang mengungkapkan respek kepada seseorang. Krama Inggil dapat disejajarkan dengan sonkeigo, Krama Andhap dapat disejajarkan dengan Kenjoogo dan Krama dapat disejajarkan dengan Teineigo. Berdasarkan hal tersebut maka dalam makalah ini pembahasan ragam hormat akan dibatasi yaitu hanya membahas Mudha Krama yang sejajar dengan Keigo dalam bahasa Jepang.

Makalah ini akan mengulas persamaan dan perbedaan antara Keigo dan Mudha Krama serta kondisi kedua ragam tersebut di kalangan generasi muda di Jepang dan Jawa saat ini.

\section{KAJIAN LITERATUR}


Suherman (2005) membandingkan struktur pembentukan tingkat tutur bahasa Jepang dan Jawa dengan pendekatan lingusitik kontrastif untuk mengetahui persamaan dan pebedaan di antara keduanya. Dalam laporan penelitiannya Imtihani (2000) menguraikan mengenai pembentukan Keigo dan perannya dalam masyarakat Jepang, sedangkan, Poedjosoedarmo (1968) menjabarkan tentang tingkat tutur bahasa Jawa secara lengkap yang disertai dengan cara-cara menentukan jenis tingkat tutur yang sesuai dengan kebutuhan dan lawan bicara. Namun dalam ketiga tulisan tersebut belum diuraikan mengenai kondisi ragam hormat pada saat ini di kalangan generasi muda Jawa dan Jepang.

\section{METODE PENELITIAN}

Data-data pada makalah ini bersumber dari kajian pustaka, dengan mencari hal-hal yang relevan dengan ragam hormat pada bahasa Jepang dan Jawa melalui berbagai media, baik cetak maupun elektronik. Metode yang digunakan dalam penelitian ini adalah deskriptif kualitatif dengan teknik analisis isi (content analysis). Metode ini berupaya memberikan gambaran keadaan yang sebenarnya yang bersandar pada data untuk memaparkan gejala-gejala, fakta-fakta, atau kejadian secara sistematis serta akurat suatu objek yang diteliti.

\section{PEMBAHASAN}

Keigo merupakan ragam bahasa yang digunakan untuk mengungkapkan rasa hormat terhadap pendengar atau orang yang dibicarakan (Ishida dalam Suherman, 1992: 7). Ragam bahasa hormat sering digunakan di antara orang yang baru saling mengenal, bawahan kepada atasan, presentasi di dalam suatu seminar, melayani tamu dan lain sebagainya. Oleh karena itu dapat dikatakan bahwa hal-hal yang mempengaruhi penggunaan Keigo adalah jenis kelamin, umur, status, tingkat keakraban, maupun suasana acara (Japanese Language Research
Group, 1992: 79). Wanita lebih sering menggunakan Keigo daripada pria. Begitu pula orang yang berusia lebih muda sering menggunakan Keigo. Di dunia pariwisata dan jasa, dalam melayani tamu, seorang karyawan harus menggunakan Keigo. Jika di antara penutur dan pendengar belum terlalu akrab, maka dalam pembicaraan juga akan digunakan Keigo.

Keigo dibagi menjadi tiga jenis yaitu Sonkeigo, Kenjoogo dan Teineigo. Teineigo sering dipakai oleh perempuan. Teineigo tidak dapat digunakan untuk mengacu pada orang ketiga atau orang yang dibicarakan. Bentuk ini merupakan penanda hubungan sopan santun antara pembicara dan pendengar. Bentuk ini dibentuk dengan cara mengubah verba bentuk biasa menjadi bentu masu atau menambah nomina atau adjektiva dengan desu.

Tabel 1. Bentuk Biasa dan Bentuk Sopan dalam Bahasa Jepang

\begin{tabular}{llll}
\hline No & $\begin{array}{c}\text { Bentuk } \\
\text { biasa }\end{array}$ & \multicolumn{1}{c}{ Teineigo } & Arti \\
\hline 1 & yomu & yomimasu & Membaca \\
\hline 2 & kaku & kakimasu & Menulis \\
\hline 3. & sensei & sensei desu & Guru \\
\hline
\end{tabular}

Sumber: Data Penelitian (2021)

Contoh:

a Mai asa Shinbuno yomu ka? 'apakah setiap pagi membaca koran?

b Mai asa Shinbun o yomimasu ka?

'Apakah setiap pagi membaca koran?'

Kalimat a adalah bentuk biasa Sedangkan kalimat $\mathrm{b}$ adalah ragam hormat Teineigo yang dibentuk dengan mengubah уоти menjadi yomimasu.. Bentuk ini semata-mata digunakan untuk memperhalus ujaran demi menghormati orang lain (tidak meninggikan maupun merendahkan siapapun).

Sonkeigo merupakan ragam bahasa hormat untuk menghormati orang lain dengan cara meninggikan derajat lawan bicara ataupun seseorang yang dibicarakan. Terdapat 3 cara pembentukan sonkeigo. Pertama adalah dengan menggunakan kata khusus. 
Berikut ini adalah kata khusus yang ada dalam Sonkeigo.

Tabel 2. Kata Khusus Sonkeigo

\begin{tabular}{lll}
\hline \multicolumn{1}{c}{$\begin{array}{c}\text { Bahasa } \\
\text { Jepang biasa }\end{array}$} & Sonkeigo & \multicolumn{1}{c}{ Arti } \\
\hline $\begin{array}{l}\text { kuru } \\
\text { iku } \\
\text { iru }\end{array}$ & irrassharu & $\begin{array}{l}\text { datang } \\
\text { pergi } \\
\text { ada }\end{array}$ \\
\hline $\begin{array}{l}\text { taberu } \\
\text { nomu }\end{array}$ & meshiagaru & $\begin{array}{l}\text { makan } \\
\text { minum }\end{array}$ \\
\hline miru & $\begin{array}{l}\text { goran } n i \\
\text { naru }\end{array}$ & melihat \\
\hline iu & ossharu & berkata \\
\hline shitte iru & gozonji & mengetahui \\
\hline shinu & nakunaru & meninggal \\
\hline suru & nasaru & melakukan \\
\hline
\end{tabular}

Sumber: IMAF (1998)

contoh kalimat:
a. Sensei ha mou tabeta ka
'apakah Pak Guru sudah makan?'
b. Sensei ha mou meshiagatta desu ka

'apakah pak guru sudah makan?'

Kalimat a adalah kalimat bahasa Jepang bentuk biasa, sedangkan kalimat $\mathrm{b}$ adalah bentuk hormat (Teineigo) dari kalimat a. Dalam kalimat b, kata tabeta diganti dengan meshiagatta. Desu dalam kalimat a merupakan kata kerja bantu yang juga menandakan kesopanan. Percakapan di atas adalah percakapan dengan konteks seorang mahasiswa yang bertanya kepada dosennya apakah beliau sudah makan atau belum. Jika mahasiswa tersebut bertanya kepada temannya apakah dosen mereka sudah makan, maka kalimatnya akan menjadi seperti berikut:

c. Sensei ha mou meshiagatta no $k a$ ?

'apakah Pak Guru sudah makan?'

Dalam kalimat c, kata kerja bantu sopan desu hilang dari dalam tuturan. Bentuk kalimat tanya pada kalimat b ditunjukan dengan intonasi naik. Dalam kalimat tersebut pembicara sudah akrab dengan lawan bicaranya (sesama mahasiswa), sehingga penanda sopan desu dihilangkan dari ujaran. Namun untuk menunjukkan respek kepada orang ketiga yaitu dosen mereka, kata 'makan' yang berkaitan dengan aktivitas yang dilakukan oleh dosen diungkapkan dengan menggunakan kata khusus yaitu 'meshiagaru' (meshiagatta untuk bentuk lampau)

Cara kedua adalah dengan menggunakan pola $O+v e r b a$ akar masu + ni naru. Jika kata yang dimaksudkan oleh pembicara tidak terdapat pada leksem khusus Sonkeigo, maka pola ini dapat digunakan. Misalnya:

matsu (machimasu) $\rightarrow$ O matchi ni naru <menunggu>

oshieru (oshiemasu) $\rightarrow O$ oshie ni naru <mengajar>

Contoh kalimat:

a Ashita gakkoo de oshieru no ka 'apakah besok mengajar di sekolah?'

b Ashita gakko de o oshie ni narimasu ka

'apakah besok mengajar di sekolah?'

Konteks kalimat b adalah seorang mahasiswa yang bertanya kepada dosennya apakah esok dosennya mengajar atau tidak. Untuk menunjukkan rasa hormatnya, pola $O+$ verba akar masu + ni naru digunakan pada kata kerja oshieru. Kata kerja bantu masu juga ditambahkan untuk menunjukkan rasa hormat. Jika yang terlibat pembicaraan adalah teman sebaya yang sedang membicarakan tentang dosennya, maka kalimat nya akan menjadi:

c. Sensei wa ashita gakkou de ooshie ni naru no ka

'apakah besok Pak Guru mengajar di sekolah?'

Cara ketiga adalah dengan menggunakan Verba +areru/ rareru. Pola ini dapat diaplikasikan pada semua verba. Namun biasanya pola ini digunakan untuk mengakomodasi verba yang tidak dapat dibentuk dengan pola $\mathrm{b}$, yaitu verba dengan bentuk masu dengan satu suku kata, misalnya:

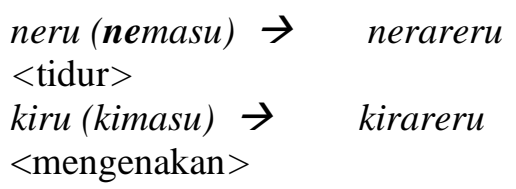


Contoh dalam kalimat :

a Tanaka san, kekkon shiki ni nani wo kiru no ka?

'Pak Tanaka, pada upacara pernikahan anda akan mengenakan pakaian apa?

b Tanaka San, kekkon shiki ni nani wo

kiraremasuka?

'Pak Tanaka, pada upacara pernikahan, Anda akan mengenakan pakaian apa?

Konteks kalimat di atas adalah saat seorang bawahan menanyakan pakaian apa yang akan dikenakan sang atasan dalam pesta pernikahan. Untuk menunjukkan respek dan hormat kepada Tanaka, maka pembicara menggunakan pola Verba+ Areru/Rareru pada kata kiru dan menambahkan kata kerja bantu masu sebagai penanda honorifik. Jika yang bercakap-cakap adalah rekan sederajat dalam perusahaan, maka kalimatnya akan berubah seperti kalimat c berikut ini:

\section{c. Tanaka san ha kekkon shiki de nani wo kirareru no ka \\ 'Pak Tanaka akan mengenakan pakaian apa pada saat upacara pernikahan?'}

Jenis ragam hormat yang kedua adalah Kenjoogo. Kenjoogo merupakan bentuk penghormatan pada lawan bicara dengan merendahkan diri. Kenjoogo digunakan untuk aktivitas-aktifitas maupun keadaan yang berhubungan dengan pembicara (Japanese Language Research Group, 1992: 80).

Pembentukan Kenjoogo bisa dilakukan dengan dua cara yaitu. Pertama adalah dengan menggunakan kata-kata khusus Kenjoogo. Sama halnya dengan Teinego, dalam Kenjoogo juga terdapat kata-kata khusus yang dapat digunakan untuk merendahkan diri sendiri dalam rangka menghormati orang lain. (lihat tabel 3)

Tabel 3. Kata Khusus Kenjoogo

\begin{tabular}{lll}
\hline \multicolumn{1}{c}{ Bentuk biasa } & Kenjoogo & \multicolumn{1}{c}{ Arti } \\
\hline iru & Oru & Ada \\
\hline suru & itasu, & melakukan \\
\hline
\end{tabular}

\begin{tabular}{lll}
\hline & mooshiageru \\
\hline morau & Itadaku & menerima \\
\hline $\begin{array}{l}\text { taberu, } \\
\text { nomu }\end{array}$ & Itadaku & $\begin{array}{l}\text { makan } \\
\text { minum }\end{array}$ \\
\hline ageru & Sashiageru & memberi \\
\hline iku & Mairu & $\begin{array}{l}\text { pergi } \\
\text { datang }\end{array}$ \\
kuru & Ukagau & bertanya \\
\hline kiku & mooshu & berkata \\
\hline iiu & zonjisuru & tahu \\
\hline shitte iru &
\end{tabular}

Sumber: IMAF (1998)

Contoh kalimat:

a Kinou okyakusama ni chippu wo moratta

'Kemarin saya mendapat tip dari tamu'

b Kinou okyakusamai ni chippu wo Itadakimashita

'Kemarin saya mendapat tip dari tamu'

Konteks kalimat tersebut adalah seorang bellboy yang berbicara kepada manajer hotel bahwa ia kemarin menerima buku dari tamu. Kalimat 5a adalah bentuk biasa dalam Bahasa Jepang. Kenjoogo digunakan pada kalimat b. Untuk menghormati dan menunjukkan respek kepada tamu ia menggunakan kata khusus Kenjoogo yaitu itadaku untuk menggantikan kata morau <menerima>. Kemudian, kata kerja bantu honorifik mashita (lampau) juga ditambahkan untuk menghormati lawan bicara (manajer).

Jika bellboy tersebut bercerita kepada temannya bahwa ia kemarin menerima uang tip dari tamu, maka kalimatnya akan menjadi:

c. Kinou, okyakusama ni chippu wo itadaita.

'kemarin saya menerima uang tip dari tamu'

Pada kalimat c, Kenjoogo "itadaku" tetap digunakan untuk menghormati oramg yang dibicarakan, tetapi bentuk honorifik -masu/-mashita dihilangkan.

Cara kedua adalah dengan menggunakan pola $\mathrm{O} /$ Go+nomina/akar kata kerja masu+suru. Pola ini digunakan jika tidak ditemuan leksem khusus dalam Kenjoogo. Misalnya: 
$\begin{aligned} & \text { motsu (mochimasu) } \\ & <\text { membawa }> \\ & \text { kaku (kakimasu } \\ & <\text { menulis }>\end{aligned}$
$\begin{aligned} & \text { denwa } \\ & <\text { menelepon }>\end{aligned}$

Contoh kalimat:

a. Watashi ga nimotsu wo motsu 'sayalah yang akan membawa barang-barang'

b Watashi wa nimotsu wo omochi shimasu

'sayalah yang akan membawa barang-barang'

Konteks kalimat tersebut adalah seorang bellboy yang menawarkan bantuan kepada tamu hotel untuk membawakan barang. Kalimat a adalah kalimat bentuk biasa. Pada kalimat b, karena aktivitas membawa merupakan aktivitas yang berhubungan dengan diri sendiri maka digunakan pola O/Go+nomina/akar kata kerja masu+suru. Sedangkan kata kerja bantu honorifik ' $m a s u$ ' digunakan untuk menghormati tamu.

Pada kalimat c, jika seorang karyawan bercerita kepada temannya bahwa ia kemarin membawakan barang milik tamu hotelnya, maka Kenjoogo tidak perlu digunakan. Berdasarkan kalimat di atas, maka pembicara tidak dapat menggunakan bentuk Teineigo untuk dirinya sendiri. Jika menyangkut dirinya sendiri maka harus digunakan Kenjoogo.

Hampir sama seperti bahasa Jepang, ragam Mudha Krama dalam Bahasa Jawa hampir sama seperti Keigo dalam bahasa Jepang. Ragam ini digunakan oleh orang yang lebih muda kepada orang yang lebih tua, dari orang yang inferior kepada orang yang superior. Untuk meninggikan orang lain digunakanlah Krama Inggil, untuk merendahkan diri sendiri untuk menghormati orang lain digunakan Krama Andhap (Setiyanto, 2007: 40).

Basa Krama juga digunakan untuk penanda kesopanan dan bentuk halus ataupun sebagai pengganti leksem jika leksem yang dimaksud tidak ditemui dalam Krama Inggil maupun Krama Andhap. Namun. berbeda dengan bahasa Jepang yang juga menggunakan sintaktik untuk membentuk ragam hormat selain penggunaan leksem khusus, dalam bahasa Jawa perbedaan antara Krama, Krama Inggil dan Krama Andhap semuanya ditunjukkan melalui perbedaan leksemnya, walaupun terdapat afiks khusus sebagai penanda bentuk Krama (Poedjosoedarmo, 1986: 61-63).

Afiks-afiks yang dimaksud adalah afiks-afiks yang digunakan untuk menandai bentuk pasif, determinan dan kausatif (Poedjosoedarmo, 1986: 58). Semua afiks (dalam tabel 4) dapat dilekatkan pada kosa kata dari tipe manapun, baik krama, Krama Inggil maupun Krama Andhap.

Tabel 4. Bentuk Imbuhan Bahasa Jawa

\begin{tabular}{lll}
\hline $\begin{array}{l}\text { Afiks } \\
\text { ngoko }\end{array}$ & Afiks krama & fungsi \\
\hline di- & dipun- & pasif \\
\hline -e & -ipun & determinan \\
\hline -(a)ke & -(a)ken & kausatif. \\
\hline Sumber
\end{tabular}

Sumber: Kuntari (2017)

Tabel 5. Leksem-Leksem Krama, Krama Inggil dan Krama Andhap

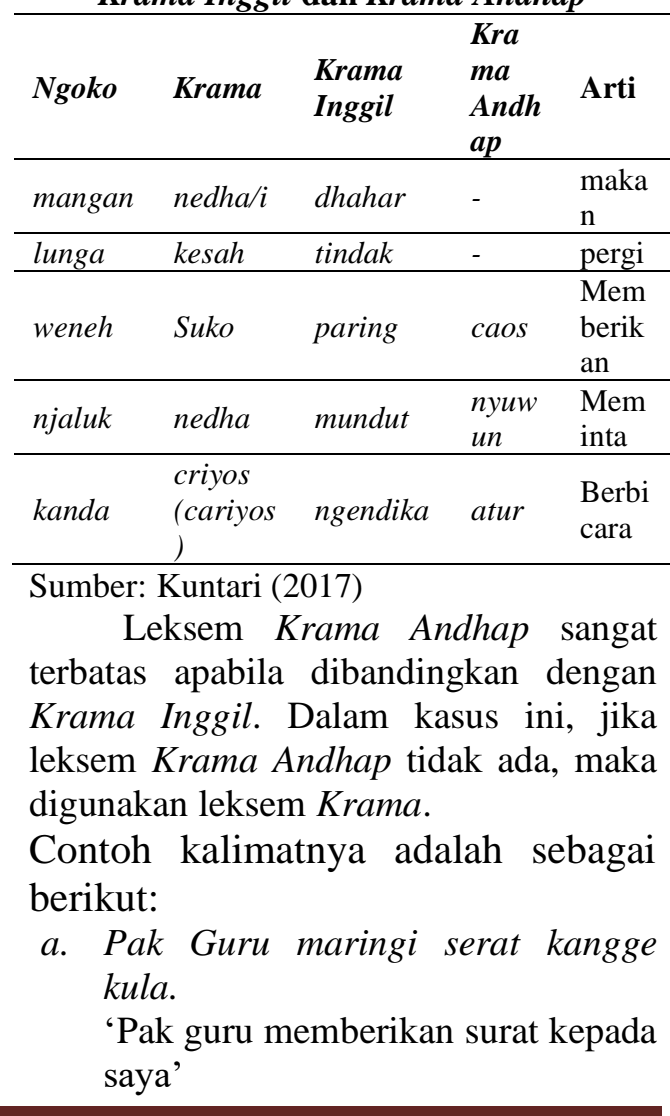

ISSN: 2355-6587, e-ISSN: 2528-2220

http://ejournal.bsi.ac.id/ejurnal/index.php/jp 
b. *Kula maringi serat kangge Pak Guru.

'Aku memberikan surat kepada Pak Guru'

c. Kula nyaosaken serat kangge Pak Guru.

'aku memberikan surat kepada Pak Guru'

Kalimat a salah karena kata maringi yang merupakan Krama Inggil tidak dapat digunakan untuk diri sendiri, maka yang tepat adalah kalimat 7.c. Konteks kalimat 7 adalah seorang siswa yang berbicara kepada guru A bahwa ia memberikan surat pada guru B. Maka dalam kalimat tersebut baik Basa Krama 'kula' <aku> dan 'serat' <surat> digunakan untuk menghormati guru A, sedangkan kata maringi digunakan untuk menghormati guru B. Kalimat tersebut juga akan menjadi kurang tepat jika kata ' $k u l a$ ' dan 'serat' tidak digunakan, seperti kalimat di bawah ini:

\section{d. * Pak Guru maringi aku layang. \\ 'Pak guru memberi aku surat'}

Kalimat d bisa saja tepat jika konteksnya berupa siswa yang berbicara kepada temannya bahwa ia diberi surat oleh gurunya. Namun dalam konteks Mudha Krama, kalimat tersebut menjadi salah karena seperti yang dikatakan sebelumnya, Mudha Krama digunakan oleh orang yang posisinya lebih rendah kepada orang dengan posisi yang lebih tinggi, sehingga terasa sangat sopan.

Di bawah ini disajikan contoh percakapan dalam ragam hormat bahasa Jepang dan Jawa. Dalam percakapan di tabel 6 kata yang dicetak tebal merupakan penanda respek kepada lawan bicara. Perbandingannya dalam bahasa Jepang dan Bahasa Jawa ditunjukkan pada tabel 7 .

Tabel 6. Perbandingan Percakapan Bahasa Sopan Jepang dan Jawa

\begin{tabular}{|c|c|}
\hline Keigo & Muda Krama \\
\hline $\begin{array}{l}\text { A:Okyakusama,ukagaita } \\
\text { koto ga arun desu }\end{array}$ & $\begin{array}{l}\text { A: Pak, kula badhe } \\
\text { nyuwun pirsa }\end{array}$ \\
\hline $\begin{array}{l}\text { kedo } \\
\text { 'Pak, saya ingin bertanya' }\end{array}$ & $\begin{array}{l}\text { 'Pak, saya ingin } \\
\text { bertanya' }\end{array}$ \\
\hline $\begin{array}{l}\text { B: Hai, nan desu ka } \\
\text { ' ya ada apa?' }\end{array}$ & $\begin{array}{l}\text { B: ana apa? } \\
\text { 'ada apa?' }\end{array}$ \\
\hline
\end{tabular}

\begin{tabular}{|c|c|}
\hline $\begin{array}{l}\text { A:Okyakusama ga } \\
\text { chuumon kudasatta } \\
\text { mono nan desu ga.. } \\
\text { 'Mengenai pesanan yang } \\
\text { Bapak sampaikan kepada } \\
\text { saya' }\end{array}$ & $\begin{array}{l}\text { A: Menawi barang } \\
\text { ingkang dipunpesen } \\
\text { dening Bapak } \\
\text { 'mengenai barang } \\
\text { yang dipesan oleh } \\
\text { Bapak' }\end{array}$ \\
\hline $\begin{array}{lr}\text { Ima made } & \text { mada } \\
\text { gozaimasen } & \text { node, } \\
\text { 'karena saya } & \text { belum } \\
\text { mendapatkan } & \text { barang } \\
\text { pesanan bapak' } & \end{array}$ & $\begin{array}{l}\text { Amargi pesenan } \\
\text { ipun dereng wonten, } \\
\text { 'karena pesanan } \\
\text { Bapak belum bisa } \\
\text { kami sediakan.' }\end{array}$ \\
\hline $\begin{array}{l}\text { Raishuu made kaado o } \\
\text { okaeshi ni shitemo ii } \\
\text { desuka } \\
\text { 'Bolehkan saya } \\
\text { mengembalikannya } \\
\text { minggu depan?' }\end{array}$ & $\begin{array}{l}\text { Menapa angsal } \\
\text { kertu menika kula } \\
\text { wangsulaken } \\
\text { minggu mbenjing? } \\
\text { 'Apakah boleh saya } \\
\text { kembalikan kartu } \\
\text { Bapak minggu } \\
\text { depan?' }\end{array}$ \\
\hline $\begin{array}{l}\text { B: Hai, ii desu yo } \\
\text { 'Iya baik tidak apa-apa' }\end{array}$ & $\begin{array}{l}\text { B: Iyo, ra papa } \\
\text { ' Iya, baik tidak } \\
\text { apa-apa' }\end{array}$ \\
\hline
\end{tabular}

Sumber: Data Penelitian (2021)

Tabel 7. Perbandingan Perubahan Kata

Bahasa Sopan Jepang dan Jawa

\begin{tabular}{lll}
\hline \multicolumn{1}{c}{ Jepang } & \multicolumn{1}{c}{ Jawa } & \multicolumn{1}{c}{ Arti } \\
\hline $\begin{array}{l}\text { Ukagau } \\
\text { kenjoogo }\end{array}$ & $\begin{array}{l}\text { Nyuwun } \\
\text { pirsa } \\
\text { krama } \\
\text { andhap }\end{array}$ & Bertanya \\
& $\begin{array}{l}\text { Dipun pesen } \\
\text { krama inggil }\end{array}$ & Dipesan \\
\hline $\begin{array}{l}\text { Chuumon } \\
\text { kudasatta } \\
\text { sonkeigo }\end{array}$ & $\begin{array}{l}\text { Dereng } \\
\text { wonten } \\
\text { gozaimasen } \\
\text { kenjoogo }\end{array}$ & belum ada \\
& $\begin{array}{l}\text { krama } \\
\text { andhap }\end{array}$ & \\
\hline $\begin{array}{l}\text { Okaeshi suru } \\
\text { kenjoogo }\end{array}$ & $\begin{array}{l}\text { Wangsulaken } \\
\text { krama }\end{array}$ & Mengembalikan \\
& andhap & \\
\hline
\end{tabular}

Sumber: Data Penelitian (2021)

Pada percakapan tersebut

pembicara menggunakan Kenjoogo untuk membahasakan aktivitas yang berhubungan dengan dirinya. Sedangkan Sonkeigo digunakan untuk membahasakan aktivitas yang dilakukan oleh gurunya. Bentuk Teineigo tidak terlihat dalam leksem tetapi diwujudkan dengan pemarkah honorifik desu dan masen (bentuk negatif dari masu). Sedangkan dalam bahasa Jawa digunakan bentuk-bentuk Krama Inggil, Krama Andhap dan Krama yang semuanya diwujudkan dalam leksem selain ada juga afiks -dipun sebagai pemarkah krama. Leksem Krama 
digunakan dalam tuturan tersebut karena tidak ada leksem Krama Andhap untuk kata 'dereng maca' dan 'wangsul'.

Seiring dengan arus globalisasi sekarang ini, nampaknya baik di Jepang maupun di Jawa pemahaman generasi muda mengenai ragam hormat semakin menurun (Suherman, 2005:3). Namun berdasarkan pengamatan penulis kondisi Keigo jauh lebih baik daripada Mudha Krama di kalangan generasi muda Jawa. Ada dua perbedaan mendasar yang menyebabkan ha tersebut terjadi, pertama adalah fenomena digglosia pada masyarakat Jawa dan tuntutan sosial yang berbeda.

Digglosia merupakan suatu fenomena dalam masyarakat tutur dimana terdapat dua varietas bahasa yang masing-masing mempunyai fungsi yang berbeda yaitu sebagai bahasa tinggi dan bahasa rendah (Holmes, 1992: 27). Masyarakat Jawa merupakan masyarakat diglosic yang menggunakan dua bahasa dalam kehidupan sehari-hari yaitu bahasa Indonesia dan bahasa Jawa. Bahasa Indonesia yang merupakan bahasa tinggi digunakan dalam berbagai bidang kehidupan, seperti pendidikan, kedinasan dan hal-h bersifat resmi. Keadaan ini membuat bahasa Jawa tergerser dan hanya digunakan sebagai bahasa pengantar untuk aspek-aspek kehidupan tidak resmi. kedaerahan dan kekeluargaan (Waljinah, 2012: 3). Ditambah lagi, pada zaman mobilitas tinggi dewasa ini, tidak hanya suku Jawa yang tinggal di antara masyarakat penutur bahasa Jawa, tetapi juga sukusuku lainnya. Keadaan ini memaksa penutur bahasa Jawa harus menggunakan bahasa Indonesia untuk berkomunikasi.

Hal-hal tersebut terutama menimbulkan dampak besar kepada generasi muda penutur bahasa Jawa, karena generasi mudalah yang tingkat mobilitas sosialnya paling tinggi. Ditambah lagi, kemajuan teknologi juga mengakibatkan generasi muda penutur bahasa Jawa terus terpapar kebudayaankebudayaan luarunakan yang semakin menggerogoti identitasnya sebagai pemuda Jawa. Salah satu ciri lunturnya identitas ke-Jawa-an tersebut adalah ketidakpahaman generasi muda Jawa dalam menggunakan ragam kebahasaan yang tetap sesuai dengan nilai sopansantun di dalam masyarakat Jawa. Menurut Poedjosoedarmo (1979: 61-62), ketidakpahaman mengenai tingkat tutur bahasa Jawa ditunjukkan dengan ketidakpandaian dalam memilih kosakata secara tepat pada tingkat tutur yang dipakainya dan tidak pandai memilih tingkat tutur yang sesuai dengan latar belakang lawan bicara. Karena takut untuk membuat kesalahan, pemuda Jawa dewasa ini cenderung memilih cara yang paling aman yaitu dengan menggunakan bahasa Indonesia kepada siapa pun lawan bicaranya.

Hal ini berbeda dengan keadaan di Jepang. Masyarakat Jepang bukan merupakan masyarakat yang diglosic. Bahasa Jepang merupakan bahasa satusatunya di Jepang yang digunakan dalam berbagai segi kehidupan (SudjiantoDahidi, 2004: 5). Dengan demikian, bahasa Jepang digunakan sebagai bahasa tinggi maupun bahasa rendah dalam kehidupan sehari-hari. Bahasa tinggi ditunjukkan dengan Keigo sedangkan bahasa rendah ditunjukkan dengan bahasa biasa (futsukei). Keigo sebagai bahasa tinggi digunakan di berbagai bidang seperti pendidikan, kedinasan maupun situasi-situasi resmi lainnya. Hal ini mau tidak mau menyebabkan generasi muda Jepang harus menguasai Keigo untuk memperlancar situasi sosial mereka (Imtihani, 2000: 1).

Seperti yang dikatakan sebelumnya. tuntutan sosial juga merupakan faktor yang membedakan situasi Keigo dan Basa Krama di Jawa. Walaupun masyarakat Jawa akan merasa malu jika tidak dapat menguasai Basa Krama, namun kemampuan Basa Krama bukanlah suatu tuntutan sosial. Maksudnya, seseorang tidak harus bisa Mudha Krama untuk sukses dalam pekerjaannya dan menjalin hubungan dengan orang lain karena fungsi tersebut telah digantikan oleh bahasa Indonesia. Namun di Jepang, tuntutan sosial 
mengharuskan masyarakatnya bisa menguasai Keigo terlebih lagi ketika seseorang telah memasuki lingkungan kerja. Kemahiran seseorang dalam Keigo secara langsung akan mempengaruhi kesuksesan seseorang dalam bekerja, menjalin hubungan dengan atasan, teman kerja, ataupun rekan bisnisnya. Apabila seseorang tidak menguasai Keigo, maka orang tersebut akan susah naik pangkat dan sangat mungkin terjadi akan dikucilkan oleh masyarakat (Imtihani, 2000: 2). Dengan demikian, generasi muda, terutama yang akan memasuki lingkungan pekerjaan mau tidak mau harus menguasai Keigo dengan baik dan benar. Meskipun demikian di Jepang juga terjadi perubahan pada Keigo walaupun tidak secara fundamental (Akagi, Bryce, and Suzuki 2020). Kenyataannya, Keigo juga tidak mudah dipahami oleh orang Jepang sendiri.

\section{PENUTUP}

Dari uraian di atas maka dapat disimpulkan jika Bahasa Jepang dan Bahasa Jawa mempunyai sistem ragam hormat yang sama. Dalam bahasa Jepang ragam hormat yang menunjukkan respek kepada orang lain diwujudkan dalam Sonkeigo, Kenjoogo dan Teineigo. Sedangkan dalam bahasa Jawa ragam hormat yang menunjukkan respek ditunjukkan dengan Mudha Krama yang terbentuk dari Krama Inggil, Krama Andhap dan Krama. Dalam bahasa Jepang ragam hormat direalisasikan menggunakan leksem serta bentuk sintaktis, sedangkan dalam bahasa Jawa direalisasikan dengan leksem dan afiks.

Walaupun generasi muda dalam kedua masyarakat tutur tersebut semakin berkurang pemahamannya mengenai ragam hormat, namun bisa dikatakan bahwa keadaan di Jepang lebih baik daripada di Jawa. Keadaan tersebut bisa terjadi karena masyarkat tutur Jawa adalah masyarakat digglosic, sedangkan di Jepang tidak. Selain itu tidak ada tuntutan sosial yang mengharuskan penggunaan Mudha Krama dalam kehidupan sehari-hari masyarakat Jawa karena fungsinya telah digantikan dengan bahasa Indonesia. Sedangkan di Jepang terdapat tuntutan sosial yang mengharuskan seseorang untuk dapat menguasai Keigo demi kehidupan sosialnya.

Dalam penelitian ini perbandingan antara ragam hormat bahasa Jawa dan Bahasa Jepang masih dibahas dalam tataran yang umum, yaitu dari segi bentuk kebahasaan dan kondsinya di kalangan generasi muda. Namun pembicaraan mengenai perbandingan ragam bahasa hormat antara Bahasa Jawa dan Jepang masih bisa diperdalam dan diperluas lagi. Misalnya, penelitian mengenai perbandingan antara kedua bahasa ini bisa dikembangkan ke arah yang lebih spesifik, misalnya mengenai preservasi bahasa, ragam hormat di lingkungan kerajaan dan lain sebaginya.

\section{REFERENSI}

Akagi, Nobuaki, Mio Bryce, and Hiroshi Suzuki. 2020. "Maji Ssu Ka? Isn't That Honorific? Ambiguity of New Japanese Honorific Ssu." Pragmatics and Society 11(4):50523.

Holmes, Janet. 1992. An Introduction to Sociolinguistics. England: Pearson Education

IMAF. 1998. Minna no Nihongo Shokyu 1 Indonesian Version. Tokyo: 3A Corporation

Imtihani, Najih. 2000. Penggunaan Bahasa Hormat (Keigo) Dalam Bahasa Jepang. Laporan Penelitian: UGM

Japanese Language Research Group. 1992. Keterangan Tata Bahasa: Dasar-Dasar Bahasa Jepang. UGM: Tidak Diterbitkan

Kuntari, Umi. 2017. Unggah-Ungguh Bahasa Jawa. Tata Cara \& Etika Penggunaan Bahasa Jawa. Yogyakarta: Pustaka Widyatama

Poedjosoedarmo, Supomo. 1968. 'Javanese Speech Level' dalam Indonesia Vol. 6. hal. 54-81 
Tingkat Tutur Bahasa Jawa. Jakarta: Pusat Pembinaan dan

Pengembangan Bahasa

Departemen Pendidikan dan Kebudayaan

Setiyanto, Aryo Bimo. 2007. Parama Sastra Bahasa Jawa.

Yogyakarta: Panji Pustaka

Sudjianto dan Dahidi. 2004. Pengantar Linguistik Jepang. Oriental: Jakarta

Suherman, Eman. 1992. Pemakaian Tingkat Tutur Bahasa Jepang Pada Masyarakat Jepang. Laporan Penelitian: UGM

Tut 2005. Tingkat

Tutur Bahasa Jepang dan Bahasa Jawa (Analisis Kontrastif). Tesis: UGM

Waljinah, Sri. 2012. Kajian Sosiodialektologi Bahasa Jawa Di Lereng Gunung Merapi. Yogyakarta: Penerbit Qinant
BIODATA PENULIS

Devita Widyaningtyas Yogyanti, S.S, M.A merupakan dosen di Universitas Bina Sarana Informatika Yogyakarta jurusan Pariwisata. Devita adalah penulis buku-buku bahasa Jepang untuk Pariwisata seperti buku Dasar dasar Bahasa Jepang untuk Pariwisata yang diterbitkan oleh Graha Ilmu dan buku Solusi Pintar Bahasa Jepang Perhotelan Untuk Pemula (Edisi Front Office) yag diterbitkan oleh CV. Prima Putra Pratama.

Mery Kharismawati, S.S., M.Si merupakan dosen tetap di Sekolah Vokasi Universitas Gadjah Mada yang mengampu mata kuliah bahasa Jepang dasar I, dan II di program studi D4 Bisnis Perjalanan Wisata. Pengabdian Masyarakat yang digeluti kerap bertema pariwisata. Salah satunya adalah webinar internasional Promosi Atraksi Budaya Kulon Progo; Melalui Fragmen Tari Bersama Mahabarata Suroloyo Wrehaspati di bulan Mei 2021 lalu. 